\title{
Low Vitamin D Intake Can Increase Prediabetes in Female Adolescents in Surakarta City
}

\author{
Nafilah $^{1}$ \\ Postgraduate of Nutrition Science \\ Universitas Sebelas Maret \\ Surakarta, Central Java, Indonesia \\ maefa.fila@gmail.com
}

\author{
Dono Indarto ${ }^{2}$ \\ Departement of Physiology \\ Faculty of Medicine, Universitas Sebelas Maret \\ Surakarta, Central Java, Indonesia \\ dono@staff.uns.ac.id
}

\author{
Adi Magna Patriadi Nuhriawangsa ${ }^{3}$ \\ Study Program of Animal Husbandry \\ Faculty of Agriculture, Universitas Sebelas Maret \\ Surakarta, Central Java, Indonesia \\ adimagna@staff.uns.ac.id
}

\begin{abstract}
Prediabetic adolescents have higher risk to suffer diabetes mellitus in adulthood periode. The role of calcium and vitamin $D$ intake in prediabetes risk is debatable. The aim of this study was to analyze the association between calcium and vitamin $D$ intake and prediabetes in adolescents. The analytic observational study was used in this study which recruited 193 students who aged 15-18 years old and studied in five senior high schools. Calcium and vitamin D intake were obtained from 1x24 hours food recall questionnaire for 3 alternating days. Fasting blood glucose levels were measured using an enzymatic colorimetric method. Collected data of this study were analyzed using the Fisher's exact and logistic regression tests with $p$ value $<0.05$. Of $2.1 \%$ female adolescents had prediabetes. All adolescents had insufficient calcium and vitamin $D$ intake. The average of calcium and vitamin $D$ intakes was $232.94 \pm 142.27$ $\mathrm{mg}$ and $1.57 \pm 1.79 \mu \mathrm{g}$, respectively. L ower mean intake of calcium and vitamin $D$ was found in $57 \%$ and $63.7 \%$ adolescents, respectively. Low calcium intake decreased 0.19 times prediabetes risk whereas low vitamin $D$ intake could increase 2.05 times prediabetes risk although it did not reach significantly ( $p=0.173$ and $p=0.552$ ). Low vitamin $D$ intake, family history of DM, and low physical activity can increase the prediabetes risk in female adolescents in Surakarta City.
\end{abstract}

Keywords-Prediabetes; Female Adolescents; Vitamin D Intake; Calcium Intake; Blood Glucose Levels

\section{INTRODUCTION}

Prevalence of prediabetes and diabetes mellitus (DM) has increased in the last decades and is expected to increase 629 million by 2045 [1]. Prediabetes and diabetes mellitus not only occur in adults but also in adolescents. Adolescents with prediabetes have 1.97 times risk to suffer diabetes mellitus in future [2]. Prevalence of prediabetes in worldwide reaches 352.1 million [1]. Prediabetic prevalence is detected in $5.4 \%$ Arabian and $4 \%$ in Nigerian adolescents [3], [4] while it has not reported yet the prediabetic prevalence in Indonesian adolescents.
Adolescents who have abnormal blood glucose levels (100$125 \mathrm{mg} / \mathrm{dl}$ ) will tend to have other metabolic disorders such as dyslipidemia and hypertension [5] by which results in decrease of life quality in future [6]. In addition, undiagnosed prediabetes can progress to DM and increase higher risk of cardiovascular diseases $(\mathrm{OR}=2.3)$, cancer $(\mathrm{OR}=1.25)$, and stroke $(\mathrm{OR}=1.21)$ [7]-[11].

Obesity is the main factor of prediabetes [1] although many factors contribute in this disorder. Controversial results have been reported the contribution of microminerals intake especially calcium and vitamin D. Gagnon and co-worker (2014) state that daily intake of $1,200 \mathrm{mg}$ calcium and 2,0006,000 IU vitamin D for 6 months can reduces prediabetic risk through improvement of insulin sensitivity [12]. Calcium intake $\geq 1,200 \mathrm{mg}$ per day can also reduce $21 \%$ the risk of diabetes mellitus [13]. In contrast with these studies, it has shown that the American adults were given $2 \times 400 \mathrm{mg}$ calcium/day for 16 weeks did not reduce the risk of DM [14]. In adolescents life, several studies have revealed that micromineral intake including calcium and vitamin $\mathrm{D}$ is lower than the recommended micromineral intake [15], [16]. Adolescents who have irregularly lunch meal will consume more fast foods and less healthy foods that consist of low fiber and micronutrients [17]. Low vitamin D intake increases 3.4 times risk of diabetes mellitus compared with high vitamin D intake. This inadequate intake will interfere insulin secretion and sensitivity through stimulation of insulin receptor expression [18], [19]. However, Ferira (2016) reports that supplementation of 4,000 IU vitamin D in American children does not affect fasting glucose levels and insulin sensitivity although they took this supplement for 12 weeks [20]. Therefore, this study aimed to analyze the association between calcium and vitamin D intake and the risk of prediabetes in adolescents. 


\section{METHODS}

\section{A. Study Design and Subjects}

This observational study was conducted in five senior high schools in Surakarta City from May to August 2017. Research subjects were selected using stratified random sampling and met the inclusion criteria: aged 15-18 years old, studied at year X and XI, and did not take any drug which could increase or reduce blood glucose levels. This research protocol was approved by the ethical committee of faculty of medicine Universitas Sebelas Maret Surakarta/Dr.Moewardi Hospital Surakarta with number 354/IV/HREC/2017.

\section{B. Data Collection}

Age, sex, and family history of DM were obtained using self-reported questionnaire. Data of calcium and vitamin D intake were obtained from selected daily intake of adolescents such as beverages and supplements. Research subjects were interviewed using $1 \times 24$ hour recall questionnaire for three alternating days. Collected data were categorized into insufficient $(<80 \%)$ and sufficient ( $>80 \%$ ) intake according to recommended dietary allowance (RDA) [21]. Physical activity data were collected using International Physical Activity Questionnaire for Adolescent (IPAQ-A) [22] and were categorized into low (<600 MET.min/week), moderate (6003000 MET.min/week) and high (>3000 MET.min/week) IPAQ scores.

Prediabetes diagnosis was determined using the American Diabetes Association (ADA) guideline [5]. Three $\mathrm{ml}$ of venous blood samples was taken from lower arms of subjects by a professional health worker. Blood glucose levels were then measured using an enzymatic colorimetric method.

\section{Statistical Analysis}

Characteristics of research subjects were presented as frequency, percentage, and mean \pm SD. Association of calcium and vitamin D intake with prediabetes was determined using Fisher's exact and logistic regression tests with degree of significance $<0.05$.

\section{RESULTS}

A total of 193 adolescents was included in this crosssectional study which female proportion was higher than male proportion. Table I showed that the adolescents aged $16.12 \pm 0.62$ years old and had $81.70 \pm 7.45 \mathrm{mg} / \mathrm{dl}$ blood glucose levels. Adolescents had no family history of DM (77.2\%), low physical activity $(53.9 \%)$, calcium intake $(232.94 \pm 142.27$ $\mathrm{mg})$, and vitamin $\mathrm{D}(1.57 \pm 1.79 \mathrm{~g})$. These food intake was much lower than the recommended calcium and vitamin D intake in Indonesian adolescents.

Because all adolescents had insufficient intake of calcium and vitamin $\mathrm{D}$, the category was modified to become less or more than mean values. Surprisingly, the majority of adolescents still had low calcium and vitamin D intake (Table I). Lower calcium and vitamin D intake was observed in 57\% and $63.7 \%$ adolescents, respectively. Prevalence of prediabetes was found in $2.1 \%$ adolescents and only in female adolescents.

According to Table II, there were difference association between micromineral intake and blood glucose levels in adolescents. Calcium intake $(\mathrm{OR}=0.245 ; 95 \% \mathrm{CI}=0.025-2.395)$ and family history of $\mathrm{DM}(\mathrm{OR}=0.28 ; 95 \% \mathrm{CI}=0.04-2.09)$ were weakly associated with blood glucose levels while moderate association was observed in vitamin $D$ intake $(O R=1.7$; 95\% CI=0.176-16.9). All associations did not reach statistically significance ( $\mathrm{p}=0.316$ and $\mathrm{p}=1.000$, respectively).

Table III showed association between micromineral intake and prediabetes after adjusted with confounding factors such as family history of DM and low physical activity. Low calcium intake decreased 0.195 times prediabetes risk, compared with high calcium intake while low vitamin D intake increased 2.054 times prediabetes risk,

TABLE I

BASIC CHARACTERISTICS OF ADOLESCENTS

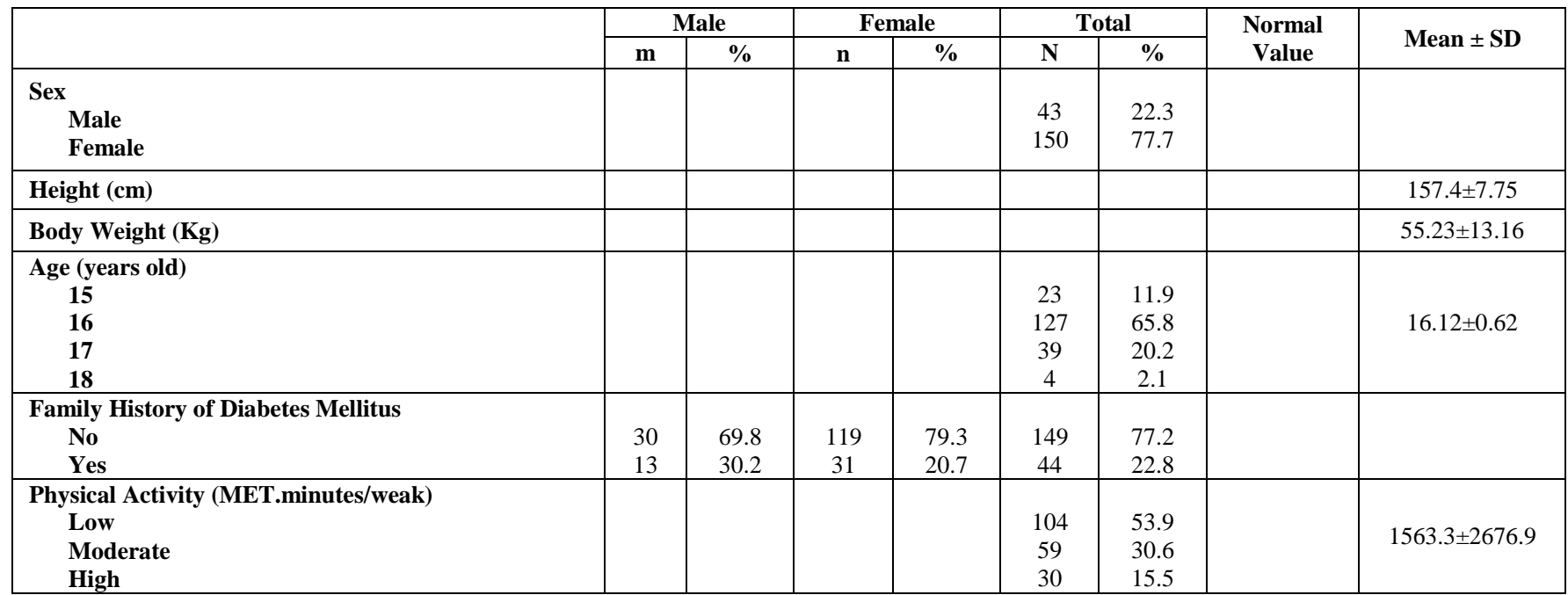




\begin{tabular}{|c|c|c|c|c|c|c|c|c|}
\hline $\begin{array}{l}\text { Fasting Blood Glucose Levels (mg/dl) } \\
\text { Normal } \\
\text { Prediabetes }\end{array}$ & $\begin{array}{c}43 \\
0\end{array}$ & $\begin{array}{c}100 \\
0\end{array}$ & $\begin{array}{c}146 \\
4 \\
\end{array}$ & $\begin{array}{c}97.3 \\
2.7\end{array}$ & $\begin{array}{c}189 \\
4\end{array}$ & $\begin{array}{c}97.9 \\
2.1\end{array}$ & $70-100$ & $81.70 \pm 7.45$ \\
\hline $\begin{array}{l}\text { Calcium Intake (mg/day) } \\
\text { Suffient } \\
\text { Insuffient }\end{array}$ & & & & & $\begin{array}{c}0 \\
193\end{array}$ & $\begin{array}{c}0 \\
100\end{array}$ & 1,200 & $232.94 \pm 142.27$ \\
\hline $\begin{array}{l}\text { Vitamin D Intake ( } \mu \mathrm{g} / \mathrm{day}) \\
\text { Suffient } \\
\text { Insuffient }\end{array}$ & & & & & $\begin{array}{c}0 \\
193\end{array}$ & $\begin{array}{c}0 \\
100\end{array}$ & 15 & $1.57 \pm 1.79$ \\
\hline $\begin{array}{l}\text { Calcium Intake (mg/day) } \\
\quad<\text { mean } \\
\geq \text { mean }\end{array}$ & & & & & $\begin{array}{c}110 \\
83\end{array}$ & $\begin{array}{l}57 \\
43\end{array}$ & 1,200 & \\
\hline $\begin{array}{l}\text { Vitamin D Intake }(\mu \mathrm{g} / \text { day }) \\
\quad<\text { mean } \\
\text { >mean }\end{array}$ & & & & & $\begin{array}{c}123 \\
70\end{array}$ & $\begin{array}{l}63.7 \\
36.3\end{array}$ & 15 & \\
\hline
\end{tabular}

TABLE II

ASSOCIATIOON BETWEEN CALCIUM AND VITAMIN D INTAKES AND PREDIABETES IN ADOLESCENTS OF 5 SENIOR HIGH SCHOOL IN SURAKARTA CITY. FISHER'S EXACT TEST WAS USED TO ANALYZED THIS RELATIONSHIP WITH P VALUE $<0.05$

\begin{tabular}{|c|c|c|c|c|c|c|c|c|}
\hline & & \multicolumn{4}{|c|}{ Blood Glucose Levels } & \multirow{3}{*}{ OR } & \multirow{3}{*}{$95 \% \mathrm{CI}$} & \multirow{3}{*}{$\mathbf{P}$} \\
\hline & & \multicolumn{2}{|c|}{ Normal } & \multicolumn{2}{|c|}{ Prediabetes } & & & \\
\hline & & $\mathrm{n}$ & $\%$ & $\mathrm{n}$ & $\%$ & & & \\
\hline \multirow{2}{*}{$\begin{array}{l}\text { Calcium } \\
\text { Intake* }\end{array}$} & High & 80 & 96.4 & 3 & 3.6 & \multirow{2}{*}{0.245} & \multirow{2}{*}{$\begin{array}{l}0.025- \\
2.395\end{array}$} & \multirow{2}{*}{0.316} \\
\hline & Low & 109 & 99.1 & 1 & 0.9 & & & \\
\hline \multirow{2}{*}{$\begin{array}{c}\text { Vitamin } \\
\text { D } \\
\text { Intake* }\end{array}$} & High & 69 & 98.6 & 1 & 1.4 & \multirow{2}{*}{1.7} & \multirow{2}{*}{$\begin{array}{c}0.176- \\
16.9\end{array}$} & \multirow{2}{*}{1.000} \\
\hline & Low & 120 & 97.6 & 3 & 2.4 & & & \\
\hline \multirow{2}{*}{$\begin{array}{c}\text { Family } \\
\text { History } \\
\text { of } \\
\text { Diabetes } \\
\text { Mellitus }\end{array}$} & No & 147 & 1.3 & 2 & 98.7 & \multirow[b]{2}{*}{0.28} & \multirow[b]{2}{*}{$\begin{array}{c}0.04- \\
2.09\end{array}$} & \multirow[b]{2}{*}{0.224} \\
\hline & Yes & 42 & 4.5 & 2 & 95.5 & & & \\
\hline
\end{tabular}

*data was catagorized into 2: low (<mean) and high ( $\$ mean)

compared with high vitamin D intake after adjusment with family history of DM and physical activity.

TABLE III

LOGISTIC REGRESION ANALYSIS: ASSOCIATIOON BETWEEN CALCIUM AND Vitamin D INTAKES AND PREDIABETES IN ADOLESCENTS OF 5 SENIOR HigH SCHOOL IN SURAKARTA CITY.

\begin{tabular}{|c|c|c|c|c|}
\hline & OR & $95 \% \mathrm{CI}$ & $\mathrm{P}$ & $\begin{array}{c}\text { Neglected } \\
\text { factor (\%) }\end{array}$ \\
\hline $\begin{array}{c}\text { Family History of } \\
\text { diabetes mellitus } \\
\text { (yes) }\end{array}$ & 3.83 & $\begin{array}{c}0.502- \\
29.223\end{array}$ & 0.195 & \\
\cline { 1 - 3 } $\begin{array}{c}\text { Low Physical } \\
\text { Activity }\end{array}$ & 2.882 & $\begin{array}{c}0.27- \\
30.27\end{array}$ & 0.378 & \multirow{2}{*}{12.9} \\
\cline { 1 - 3 } Low Calcium & 0.195 & $\begin{array}{c}0.019- \\
2.043\end{array}$ & 0.173 & \\
\hline Low Vitamin D & 2.054 & $\begin{array}{c}0.19- \\
22.06\end{array}$ & 0.552 & \\
\hline Intake & & & \\
\hline
\end{tabular}

\section{DISCUSSION}

In this study, we have firstly documented that the prevalence of prediabetes in female adolescents was $2.1 \%$ in Surakarta City. Two prediabetic adolescents had family history of DM.In addition, approximately a half of adolescents in Surakarta City had low physical activity. Surprisingly, all adolescents who participated in this study have inadequate vitamin $\mathrm{D}$ and calcium intake. Low vitamin $\mathrm{D}$ intake increased whereas low calcium intake decreased prediabetes risk despite of family history of DM and physical activity. All together, these results suggest that family history of DM, physical activity and vitamin D intake are the most important factors affecting prediabetic prevalence in adolescents.

Interestingly, our results indicated that prediabetes was only found in female adolescents. The prevalence of this study is around 3 folds lower than the global prevalence of adult prediabetes (20-79 years old). Other studies conducted in Middle East Asia showed that prediabetes prevalence in Saudi Arabia and Qatar was 5.4\% and 4.2\% respectively [3] [23]. Perhaps, the discrepancy of this prevalence is caused by age range. Amiri and Mamtani studies recruited adolescents who age 11-18 years old while our study used 15-18 years old. Another reason is more likely related to genetic, socioeconomics, and environmental factors [24].

There are three possible reasons why female adolescents have higher risk of prediabetes. At first, insulin sensitivity in early female adolescents ( 11 years old) theoretically decreases at tanner 1 and rises at tanner 5 by 15 years old [25]. However, our study showed opposite results and the prediabatic adolescents may have reduced insulin sensitivity, compared with normal female adolescents. Secondly, 50\% prediabetic female adolescents have family history of DM although we do not distinguish whether their father, mother or relatives suffers DM. In Middle and North Mexico, family history of DM increases 11.7 time risk of prediabetes in adolescents [26] although the researchers do not consider the sex factor. The last reason is because most female adolescents were involved in this study (data is not shown) and they had low physical activity. This result study is in line with other studies conducted in Poland, Spain and some countries in Europe, Africa, America and Asia [27]-[29]. They reported that the majority of female adolescents spend more time to do homework at home and to watch television [28].

Our findings show that all adolescents have lower calcium and vitamin D intake than RDA. This result is similar to several studies conducted in Australia and the United States [15], [16]. In contrast with our study, Larson and her colleagues stated that calcium intake at 15 years old was significantly higher than calcium intake at 20 years old [30]. In this study, most adolescents consumed more junk foods and 
less vegetables, fruits, fish and milk as calcium and vitamin D sources. In addition to our study, reduction of micronutrient intake is common in adolescents who have lunch with high fast foods and less healthy foods [17].

Gupta and Deleskog also reported that low intake of vitamin D could increase prediabetes risk [31], [32]. Another study showed that low serum $25(\mathrm{OH}) \mathrm{D}$ could increase progression of DM in prediabetic adults (35-56 years) [32]. Moreover, Korean adults have deficiency intake of vitamin D can increase 3.4 times risk of DM [18].

Theoretically, adequate intake of vitamin D helps insulin secretion and sensitivity in pancreatic beta cells [12], [33], [34]. The mechanism underlying vitamin D actions through direct and indirect pathways [35]. An active form of vitamin D $(1.25(\mathrm{OH})$ D) interacts with vitamin $\mathrm{D}$ receptor in pancreatic beta cells which results in activation of insulin promoter gene. While the indirect pathway is incorporated with the calcium channel in pancreatic beta cells but molecular mechanism of this pathway remains unknown. Therefore vitamin D deficiency can disrupt insulin gene transcription and calcium channel activity, leading to reduction of insulin secretion and sensitivity [33], [36].

\section{CONCLUSIONS}

Low vitamin D intake can increase prediabetes risk of female adolescents in Surakarta City in conjunction with family history of DM and low physical activity. Further investigation of serum vitamin D levels and blood glucose levels after oral glucose loading is required to verify the prediabetic status in female adolescents.

\section{ACKNOWLEDGMENT}

We would like to thank Sarana Medical Laboratory for analysis of blood glucose levels and the headmasters of five senior high schools for allowing to conduct this research study. We also thank Prof. Bhisma Murti, dr., MPH, M.SC, $\mathrm{PhD}$ for his guidance of statistical analysis, enumerators and friends for helping this research study.

\section{REFERENCES}

[1] International Diabetes Federation, IDF Diabetes Atlas Eighth Edition 2017. International Diabetes Federation, 2017.

[2] M. Sadeghi, M. Talaei, E. Parvaresh Rizi, M. Dianatkhan, S. Oveisqharan, and N. Sarrafzadegan, "Determinan of Incident Prediabetes and Type 2 Diabetes in a 7-year Cohort in a Developing Country: The Isfahan Cohort Study.” J Diabetes, Sep-2015.

[3] E. Al Amiri, M. Abdullatif, A. Abdulle, N. Al Bitar, E.Z. Afandi, M. Parish, and G. Darwiche, "The prevalence, risk factors, and screening measure for prediabetes and diabetes among Emirati overweight/obese children and adolescents," BMC Public Health, vol. 15, no. 1, Dec. 2015.

[4] O. Arigbede, I. Adeoye, O. Jarrett, and O. Yusuf, "Prediabetes among Nigerian adolescents: A School-based study of the prevalence, risk factors and pattern of fasting blood glucose in Ibadan, Nigeria," Int. J. Diabetes Dev. Ctries., vol. 37, no. 4, pp. 437-445, Dec. 2017.

[5] American Diabetes Association, "Standar of Medical Care in Diabetes - 2017," Diabetes Care, vol. 40, no. 1, Jan. 2017.

[6] M. I. Constantino, L. Molyneaux, F. Limacher-Gisler, A. Al-Saeed, C. Lou, T. Wu, S.M. Twigg, D.K. Yue, and J. Wong, "Long-Term
Complications and Mortality in Young-Onset Diabetes: Type 2 diabetes is more hazardous and lethal than type 1 diabetes," Diabetes Care, vol. 36, no. 12, pp. 3863-3869, Dec. 2013.

[7] E. R. F. Collaboration, "Diabetes mellitus, fasting glucose, and risk of cause-specific death," N Engl J Med, vol. 2011, no. 364, pp. 829-841, 2011.

[8] F. Bacha, S. Lee, N. Gungor, and S. A. Arslanian, "From PreDiabetes to Type 2 Diabetes in Obese Youth: Pathophysiological characteristics along the spectrum of glucose dysregulation," Diabetes Care, vol. 33, no. 10, pp. 2225-2231, Oct. 2010.

[9] E. S. Ford, G. Zhao, and C. Li, "Pre-diabetes and the risk for cardiovascular disease," J. Am. Coll. Cardiol., vol. 55, no. 13, pp. 1310-1317, 2010.

[10] M. Lee, J. L. Saver, K.-S. Hong, S. Song, K.-H. Chang, and B. Ovbiagele, "Effect of pre-diabetes on future risk of stroke: metaanalysis," BMJ, vol. 344, no. jun07 3, pp. e3564-e3564, Jun. 2012.

[11] M. R. Salazar, H. Carbajal, W.G. Espeche, M. Aizpurua, C. Leiva Sisnieguez, B. Leiva Sisnieguez, R.N. Stavile, C.E. March, and G.M. Reaven, "Insulin resistance: the linchpin between prediabetes and cardiovascular disease," Diab. Vasc. Dis. Res., vol. 13, no. 2, pp. $157-$ 163, 2016.

[12] C. Gagnon, R.M. Daly, A. Carpentier, Z.X. Lu, C.Shore-Lorenti, K Sikaris, S. Jean, P.R. Ebeling, and H.K. Berthold, "Effects of Combined Calcium and Vitamin D Supplementation on Insulin Secretion, Insulin Sensitivity and $\beta$-Cell Function in Multi-Ethnic Vitamin D-Deficient Adults at Risk for Type 2 Diabetes: A Pilot Randomized, Placebo-Controlled Trial," PLoS ONE, vol. 9, no. 10, p. e109607, Oct. 2014.

[13] A. G. Pittas, B. Dawson-Hughes, T. Li, R.M. Van Dam, W.C. Willet, J.E. Manson, and F.B. Hu, "Vitamin D and calcium intake in relation to type 2 diabetes in women," Diabetes Care, vol. 29, no. 3, pp. 650656, 2006.

[14] J. Mitri, B. Dawson-Hughes, F. B. Hu, and A. G. Pittas, "Effects of vitamin $D$ and calcium supplementation on pancreatic cell function, insulin sensitivity, and glycemia in adults at high risk of diabetes: the Calcium and Vitamin D for Diabetes Mellitus (CaDDM) randomized controlled trial," Am. J. Clin. Nutr., vol. 94, no. 2, pp. 486-494, Aug. 2011.

[15] C. Whitton, S.K. Nicholson, C. Roberts, C.J. Prynne, G.K. Pot, A Olson, E. Fitt, D. Cole, B. Teucher, B. Bates, H. Henderson, S. Pigott, C. Deverill, G. Swan, and A.M. Stephen, "National Diet and Nutrition Survey: UK food consumption and nutrient intakes from the first year of the rolling programme and comparisons with previous surveys," $\mathrm{Br}$. J. Nutr., vol. 106, no. 12, pp. 1899-1914, Dec. 2011.

[16] C. Gallagher, L. Black, and W. Oddy, "Micronutrient Intakes from Food and Supplements in Australian Adolescents," Nutrients, vol. 6, no. 1, pp. 342-354, Jan. 2014.

[17] K. C. Mathias, E. Jacquier, and A. L. Eldridge, "Missing Lunch Is Associated with Lower Intakes of Micronutrients from Foods and Beverages among Children and Adolescents in the United States," J. Acad. Nutr. Diet., vol. 116, no. 4, p. 667-676.e6, Apr. 2016.

[18] S. Lim, M.J. Kim, S.H. Choi, C.S. Shin, K.S. Park, H.C. Jang, L.K Billings, and J.B. Meigs, "Association of vitamin D deficiency with incidence of type 2 diabetes in high-risk Asian subjects," Am. J. Clin. Nutr., vol. 97, no. 3, pp. 524-530, Mar. 2013.

[19] H. Wagner, M. Alvarsson, B. Mannheimer, M. Degerblad, and C.-G. Östenson, "No Effect of High-Dose Vitamin D Treatment on $\beta$-Cell Function, Insulin Sensitivity, or Glucose Homeostasis in Subjects With Abnormal Glucose Tolerance: A Randomized Clinical Trial," Diabetes Care, vol. 39, no. 3, pp. 345-352, Mar. 2016.

[20] A. J. Ferira, E.M. Laing, D. Hausman, D.B. Hall, G.P. McCabe, B.R Martin, K. Hill Gallant, S.J. Warden, C.M. Weaver, M. Peacock, and R.D. Lewis "Vitamin D Supplementation Does Not Impact Insulin Resistance in Black and White Children," J. Clin. Endocrinol. Metab., vol. 101, no. 4, pp. 1710-1718, Apr. 2016.

[21] Indonesia Ministry of Health, Indonesia Ministry of Health Regulation Number 75/2013. Jakarta: Indonesia Ministry of Health, 2013.

[22] International Physical Activity Questionnaire, "Guidelines for Data Processing and Analysis of International Physical Activity Questionnaire (IPAQ)-Short and Long Forms,” Nov. 2005. 
[23] R. Mamtani, A.B. Lowenfels, J. Sheikh, S. Cheema, A. Al-Hamaq, S.A. Matthis, K.G. El-Nahas, and P. Maisonneuve "Adolescent prediabetes in a high-risk Middle East country: a cross-sectional study," JRSM Open, vol. 5, no. 8, p. 205427041453655 , Jul. 2014.

[24] T. Jaja, A. O. Oduwole, B. Fetuga, and I. A. Abdus-Salam, "Prevalence of prediabetes in secondary school students in Port Harcourt, Nigeria," Afr. J. Diabetes Med. Vol, vol. 23, no. 1, 2015.

[25] L. A. Kelly, C. J. Lane, M. J. Weigensberg, C. M. Toledo-Corral, and M. I. Goran, "Pubertal Changes of Insulin Sensitivity, Acute Insulin Response, and $\beta$-Cell Function in Overweight Latino Youth," $J$. Pediatr., vol. 158, no. 3, pp. 442-446, Mar. 2011.

[26] M. Rodríguez-Moran, F. Guerrero-Romero, C. Aradilas-Garcia, R. Violante, L.E. Simental-Mendia, E. Monreal-Escalante, and E. De La Cruz Mendoze, "Obesity and family history of diabetes as risk factors of impaired fasting glucose: implications for the early detection of prediabetes," Pediatr. Diabetes, vol. 11, no. 5, pp. 331-336, Nov. 2009.

[27] R. Guthold, M. J. Cowan, C. S. Autenrieth, L. Kann, and L. M. Riley, "Physical Activity and Sedentary Behavior Among Schoolchildren: A 34-Country Comparison," J. Pediatr., vol. 157, no. 1, p. 43-49.e1, Jul. 2010.

[28] J. Bergier, L. Kapka-Skrzypczak, P. Bilinski, P. Paprzycki, and A. Wojtyla, "Physical activity of Polish adolescents and young adults according to IPAQ: a population based study," Ann. Agric. Environ. Med., vol. 19, no. 1, 2012

[29] M. Bibiloni, A. Özen, A. Pons, M. González-Gross, and J. Tur "Physical Activity and Beverage Consumption among Adolescents," Nutrients, vol. 8, no. 7, p. 389, Jun. 2016
[30] N. I. Larson, D. Neumark-Sztainer, L. Harnack, M. Wall, M. Story, and M. E. Eisenberg, "Calcium and Dairy Intake: Longitudinal Trends during the Transition to Young Adulthood and Correlates of Calcium Intake," J. Nutr. Educ. Behav., vol. 41, no. 4, pp. 254-260, Jul. 2009.

[31] A. K. Gupta, M. M. Brashear, and W. D. Johnson, "Prediabetes an Prehypertension in Healthy Adults Are Associated With Low Vitamin D Levels," Diabetes Care, vol. 34, no. 3, pp. 658-660, Mar. 2011.

[32] A. Deleskog, A. Hilding, K. Brismar, A. Hamsten, S. Efendic, and C.G. Östenson, "Low serum 25-hydroxyvitamin D level predicts progression to type 2 diabetes in individuals with prediabetes but not with normal glucose tolerance," Diabetologia, vol. 55, no. 6, pp 1668-1678, Jun. 2012

[33] T. D. Thacher and B. L. Clarke, "Vitamin D insufficiency," in Mayo Clinic Proceedings, 2011, vol. 86, pp. 50-60.

[34] C. Gagnon, Z.X. Lu, D.J. Magliano, D.W. Dunstan, J.E. Shaw, P.Z Zimmet, K. Sikaris, N. Grantham, P.R. Ebeling, and R.M. Daly, "Serum 25-Hydroxyvitamin D, Calcium Intake, and Risk of Type 2 Diabetes After 5 Years: Results from a national, population-based prospective study (the Australian Diabetes, Obesity and Lifestyle study)," Diabetes Care, vol. 34, no. 5, pp. 1133-1138, May 2011.

[35] T. Mezza, G. Muscogiuri, G.P. Sorice, A. Prioletta, E. Salomone, A. Pontecorvi, and A. Giaccari, "Vitamin D Deficiency: A New Risk Factor for Type 2 Diabetes," Ann. Nutr. Metab., vol. 61, no. 4, pp. 337-348, 2012.

[36] E. Angellotti and A. G. Pittas, "The Role of Vitamin D in the Prevention of Type 2 Diabetes: To D or Not to D?," Endocrinology, vol. 158 , no. 7, pp. 2013-2021, Jul. 2017. 